\title{
ATG7 Gene
}

National Cancer Institute

\section{Source}

National Cancer Institute. ATG7 Gene. NCI Thesaurus. Code C120963.

This gene plays a role in both autophagy and the transport of cytoplasmic molecules to vacuoles. 